\title{
EFFECTIVE METHODS OF PYRIDOXINE SUPPLEMENTATION IN LAYING HENS TO ALBUMIN AND GLOBULIN LEVELS
}

\author{
S. Silaban ${ }^{1, *}$, B. Sinaga ${ }^{2}$, M. Damanik ${ }^{1}$ and P. M. Silitonga ${ }^{1}$ \\ ${ }^{1}$ Department of Chemistry, Universitas Negeri Medan, Medan 20221, Indonesia \\ ${ }^{2}$ Department of Mathematics, Universitas Negeri Medan, Medan 20221, Indonesia \\ *E-mail: saronomsilaban@unimed.ac.id
}

\begin{abstract}
This research investigates the effective methods of pyridoxine supplementation to enhance the protein (albumin and globulin) level of chicken egg. 12 laying hens that been ready to produce eggs were categorized into three groups based on pyridoxine supplementation methods (via drinking water, ration, and intravenous injection). Each group received supplementation pyridoxine treatment with dosage of $3 \mathrm{mg} / \mathrm{kg}$ ransoms for 68 days. The albumin and globulin levels were analyzed using Folin's Fenol technique and compared to the standard egg. We found that only albumin level could be enhanced. The intravenous injection was the most effective method to significantly increase the albumin levels compared.
\end{abstract}

Keywords: Albumin, Globulin, Egg, Laying Hens, Supplementation of pyridoxine

(C) RASĀYAN. All rights reserved

\section{INTRODUCTION}

The egg is one of the familiar foods in our daily life. Egg chicken has been recognized as one of very nutritious food since it contains high-quality protein, vitamin, carbohydrate, fat, and easy to digest. ${ }^{1-5}$

Albumin and globulin are the main proteins of egg. Generally, albumin and globulin levels in an egg are about 4.0-5.9 and 3.0-5.0 g/dL, respectively. ${ }^{6,7}$ Albumin has a role to control the blood osmotic pressure through spreading the body fluid, while globulin is useful to control ion circulation, hormone, and fatty acids in human's body. Moreover, globulin can bind with hemoglobin, transport iron substance, coagulation factors, and as antibodies to attack the germs. ${ }^{6}$ Since the albumin and globulin are the vital proteins in eggs the pyridoxine as coenzymes should involve in biosynthesis of those proteins fractions. The availability of pyridoxine consumed by laying hens not only determines the rate of albumin and globulin in biosynthesis but also determines the albumin-globulin content that transferred into the chicken egg.

Eggs quality are determined by the quality and health of laying hens that produce it. If the laying hens are maintained with a right level of health and given a ration with sufficient nutritional value, the eggs quality will be high. ${ }^{8,9}$ Researchers have made various efforts in order to produce the excellent quality of eggs which have excellent nutritional value and optimum protein content. One effort that has been done by the addition of pyridoxine (vitamin B6) in rations. ${ }^{10-12}$ The Pyridoxine that needs for laying hens is $4.5 \mathrm{mg} / \mathrm{kg}$ of ration. However, in general pyridoxine present with a dose of $3.0 \mathrm{mg} / \mathrm{kg}$ ration has been sufficient to provide a healthy life for laying hens. ${ }^{13}$ The gold of this study is to find the easiest and the most effective method of pyridoxine supplementation in order to produce eggs with high protein content.

\section{EXPERIMENTAL}

Materials, Experimental Design and Management

This research was conducted at Chemical Laboratory of State University of Medan. 12 adult laying hens (Isa brown kind) that had been ready to lay egg were used as the samples. The vitamin B6 (pyridoxine)

Rasayan J. Chem., 13(1), 434-438(2020)

http://dx.doi.org/10.31788/RJC.2020.1315506

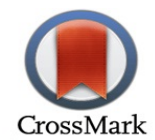


RASĀYAN J. Chem.

Vol. 13 | No. 1 |434 - 438| January - March | 2020

with dose of $3.0 \mathrm{mg} / \mathrm{kg}$ of rations was used as coenzyme to stimulate the biosynthesis of albumin and globulin. Bovine Serum Albumin (BSA) (Sigma-Aldrich) was used as the standard protein. The commercial rations that already contained the regular dose of pyridoxine was used as the rations. All experiment was performed using a Completely Randomized Design (CRD) with three treatments and each treatment was repeated for four times. The 12 laying hens were separated into three groups based on pyridoxine supplementation treatment. The groups that threat via drinking water, via ration and via intravenous injection were denoted as S-1, S-2 and S-3, respectively. Maintenance and care of samples were carried out by following the Bugos's procedure. ${ }^{14}$

\section{Maintenance and Provision of Treatment on Laying Hens}

Before starting the experiment, a rectangular cage with size of $45 \times 30 \times 45 \mathrm{~cm}$ was built in a row overlapping each other. It consisted of 6 cages at the front and six cages at the rear. The cage door located at the top. The cage floors made of bamboo slats that sparsely arranged to let the chicken manure directly fall down to the ground. Each laying hens was inserted into a cage and the maintenance carried out for 68 days. During the maintenance, all the laying hens was given water to drink and standard commercial rations trough ad libitum feeding. After 14 days of adaptation in the cage, the sample was given supplementation pyridoxine at a dose of $3.0 \mathrm{mg} / \mathrm{kg}$ ration. On $68^{\text {th }}$ day, the eggs were collected to determine the albumin and globulin levels.

\section{Determination of Albumin and Globulin Levels}

Determination albumin protein and globulin levels in egg sample were done by Folin's Fenol procedure. ${ }^{15}$ In detail, $0.5 \mathrm{~mL}$ of egg sample was poured into a tube reaction followed by adding $9.5 \mathrm{~mL} \mathrm{Na} \mathrm{NO}_{4}$ $(22.5 \%)$ solution. After that the sample was soaked into another beaker glass containing $37^{\circ} \mathrm{C}$ water for 2 hours. Sample was then filtered by using filter paper to obtain albumin filtrate and globulin sediment. Afterward, the obtained sediment was moved on the top of measure flask $50 \mathrm{~mL}$. The filter paper was carefully perforated and then washed with $\mathrm{NaOH} 0.01 \mathrm{M}$ solution followed by distillated water. $20 \mu \mathrm{L}$ of protein standard Bovine Serum Albumin (BSA) from Sigma-Aldrich was poured out into standard tube. Three flask measures were prepared with flask 1 for albumin protein, flask 2 for globulin protein and flask 3 for standard protein (see Table-1). Finally, its absorbance was measured at a wavelength of 570 $\mathrm{nm}$ to determine the albumin and globulin level according to below formula:

$$
\begin{aligned}
& \text { Albumin levels }=\frac{\text { Sample absorbance }}{\text { Standard absorbance }} \times \text { Standard concentration }(5 \mathrm{~g} / 100 \mathrm{~mL}) \\
& \text { Globulin levels }=\frac{\text { Sample absorbance }}{\text { Standard absorbance }} \times \text { Standard concentration }(5 \mathrm{~g} / 100 \mathrm{~mL})
\end{aligned}
$$

Table-1: The Reaction Analysis of Albumin and Globulin Levels using Folin's Phenol Method

\begin{tabular}{c|c|c|c}
\hline Reaction & Flask & Flask $~$ & Flask 3 \\
\hline $\begin{array}{c}\text { Filtrate Albumin or } \\
\text { Globulin }\end{array}$ & $5 \mathrm{~mL}$ & $5 \mathrm{~mL}$ & $4 \mathrm{~mL}$ \\
\hline BSA Standards & - & - & $25 \mathrm{~mL}$ \\
\hline Aquades & $25 \mathrm{~mL}$ & $25 \mathrm{~mL}$ & $2 \mathrm{~mL}$ \\
\hline $\mathrm{NaOH}$ & $2 \mathrm{~mL}$ & $2 \mathrm{~mL}$ & $2 \mathrm{~mL}$ \\
\hline Folin's Fenol & $3 \mathrm{~mL}$ & $3 \mathrm{~mL}$ &
\end{tabular}

\section{Data Analysis}

The albumin and globulin levels that obtained from measurements were further statistically analyzed using analysis of variance (ANOVA). Hypothesis test was done at the significant level of $\alpha=0.05$. If there was significant effect then least statistics different (LSD) test was then further conducted.

\section{Analysis of Albumin Levels}

\section{RESULTS AND DISCUSSION}

Table-2 lists the albumin levels from pyridoxine supplementation with dosage of $3.0 \mathrm{mg} / \mathrm{kg}$ rations by different methods. The average of albumin levels from pyridoxine supplementation via drinking water, 
RASĀYAN J. Chem.

Vol. 13 | No. 1 |434 - 438| January - March | 2020

ration and intravenous injection are $6.16,7.29$ and $9.76 \mathrm{~g} / \mathrm{dL}$, respectively. It is found that the intravenous injection was the most effective method to give the highest albumin level. The albumin levels of pyridoxine supplementation by those three methods were significantly higher compared to the standard egg with albumin level of about 4.0-5.9 $\mathrm{g} / \mathrm{dL}$.

Table-2: Average Albumin Level by Different Methods with Pyridoxine Dosage of $3.0 \mathrm{mg} / \mathrm{kg}$ Ration

\begin{tabular}{c|c|c|c}
\hline \multirow{2}{*}{ Variables } & \multicolumn{3}{|c}{ Variations of Pyridoxine Supplementation Methods } \\
\cline { 2 - 4 } & Via Drinking Water & Via Ration & Via Intravenous Injection \\
\hline Average albumin level $(\mathrm{g} / \mathrm{dL})$ & $6.16 \pm 0.87$ & $7.29 \pm 0.76$ & $9.76 \pm 1.18$ \\
\hline
\end{tabular}

Table-3 shows the result of analysis of variance for albumin level of chicken egg after pyridoxine supplementation with different methods. Since the $F_{\text {calculate }}(13.01)$ is greater than $F_{\text {table }}(10.92)$ then the hypothesis (Ho) is rejected which means there is a significant effect of pyridoxine supplementation on albumin level. Furthermore, the Least Significance Different (LSD) test also proved that albumin level via intravenous injection was significantly higher compared to via drinking water and via ration, as shown in Fig.-1.

Table-3: Analysis of Variance Albumin Levels of Chicken Egg Via Drinking Water, Ration, and Intravenous Injection

\begin{tabular}{c|c|c|c|c|c}
\hline Sources of Diversity & DF & SS & MS & $\mathrm{F}_{\text {cal. }}$ & $\mathrm{F}_{\text {table }}(0.01 \mathrm{DF})$ \\
\cline { 1 - 4 } Treatment & 2 & 20.35 & 10.17 & \multirow{2}{*}{13.01} & \multirow{2}{*}{10.92} \\
\hline Error & 6 & 4.69 & 0.78 & & \\
\hline Total & 8 & 25.04 & 10.95 & & \\
\hline
\end{tabular}

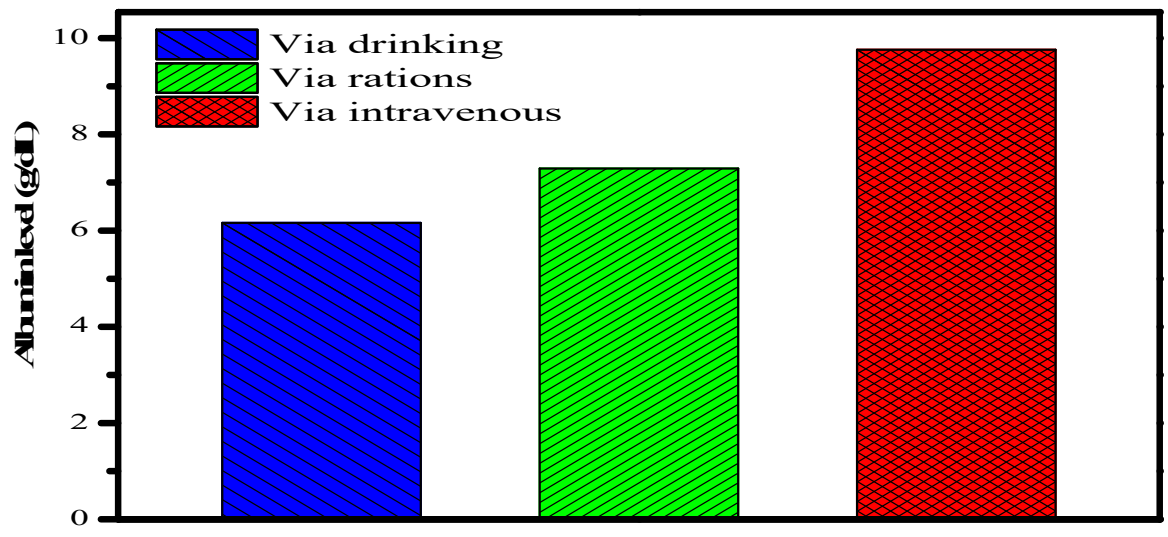

Supplementation method

Fig.-1: Albumin Levels of Chicken Egg by Different Methods with Pyridoxine Dosage of $3.0 \mathrm{mg} / \mathrm{kg}$ Ration

\section{Analysis of Chicken Egg Globulin Protein Levels}

Table-4 shows the globulin levels of egg that supplemented with pyridoxine $(3.0 \mathrm{mg} / \mathrm{kg}$ ration) for various treatments. The globulin levels via drinking water, ration and intravenous injection are 4.44, 3.20 and $3.94 \mathrm{~g} / \mathrm{dL}$, respectively. The average globulin levels for those treatments are similar to the standard globulin level of 3-5 g/dL. Furthermore, analysis of variance indicates that globulin level of chicken egg after pyridoxine supplementation via drinking water, ration, and intravenous injection was not significantly different, as shown in Table-5.

Table-4: Average Globulin Levels of Chicken Egg Supplemented with Pyridoxine Dosage of $3.0 \mathrm{mg} / \mathrm{kg}$ Ration

\begin{tabular}{c|c|c|c}
\hline \multirow{2}{*}{ Variables } & \multicolumn{3}{|c}{ Variations of Pyridoxine Supplementation Methods } \\
\cline { 2 - 4 } & Via Drinking Water & Via Ration & Via Intravenous Injection \\
\hline Mean globulin egg level $(\mathrm{g} / \mathrm{dL})$ & $4.44 \pm 0.88$ & $3.204 \pm 1.01$ & $3.941 \pm 0.30$ \\
\hline
\end{tabular}


RASĀYAN J. Chem.

Vol. 13 | No. 1 |434 - 438| January - March | 2020

Table-5: Analysis of Variance Globulin Level of Chicken Egg Via Drinking Water, Ration, and Intravenous

\begin{tabular}{|c|c|c|c|c|c|}
\hline & & & 100 & & \\
\hline Sources of Diversity & DF & SS & MS & $\mathrm{F}_{\text {cal. }}$ & $\mathrm{F}_{\text {table }}(0.01 \mathrm{DF})$ \\
\hline Treatment & 2 & 2.33 & 1.16 & \multirow{3}{*}{1.84} & \multirow{3}{*}{10.92} \\
\hline Error & 6 & 3.80 & 0.63 & & \\
\hline Total & 8 & 6.14 & 1.80 & & \\
\hline
\end{tabular}

Pyridoxine is a water-soluble compound and acts as a coenzyme to help facilitate the metabolism of carbohydrates, fats, and proteins. ${ }^{16}$ Vitamin supplementations in layer diet remained indispensable due to their participation in all biochemical processes and chicken gut flora provides minimum vitamin synthesis but competes with the host for dietary vitamins. ${ }^{4,17,18}$ Chicken eggs contain high-quality proteins, carbohydrates, easily digestible fats, and minerals, as well as valuable vitamins. ${ }^{19,20}$ Poultry is susceptible to vitamin deficiency because the microorganisms can cause it in the digestive tool of poultry. Poultry needs large amounts of vitamins since they cannot synthesize vitamins for the ongoing reactions of metabolism in the body. ${ }^{21-23}$

Normal albumin level in chicken eggs are about 4.0 to $5.9 \mathrm{~g} / \mathrm{dL}$. It is concluded that the albumin levels after pyridoxine supplementation by each method is increased compared to the normal levels. It causes pyridoxal phosphate (PLP) is a versatile coenzyme. It can play a role to catalyse the important reactions in the metabolism of amino acids and proteins. ${ }^{24-28} \mathrm{As}$ it is known that there are about 60 types of amino acid reactions involving pyridoxal phosphate. ${ }^{29}$ Therefore, the pyridoxine plays the important role in the formation of protein in chicken eggs, especially in albumin level.

\section{CONCLUSION}

Three different methods of pyridoxine supplementation via drinking water, ration, and intravenous injection could only significantly enhance the albumin protein levels of chicken egg. Supplementation of pyridoxine via intravenous injection was the most effective method for increasing levels of egg albumin protein. The globulin level after pyridoxine supplementation was similar to the standard chicken egg.

\section{ACKNOWLEDGMENT}

This work was supported by Faculty of Mathematics and Natural Sciences, Universitas Negeri Medan, Medan-Indonesia.

\section{REFERENCES}

1. Y. Mine and J. Kovacs-Nolan, The Journal of Poultry Science, 41(1), 1(2004), DOI:10.2141/jpsa.41.1

2. R. Huopalahti, R. López-Fandiño, M. Anton and R. Schade, (Eds.). Bioactive egg compounds. Springer-Verlag Berlin Heidelberg, (2007), DOI:10.1007/978-3-540-37885-3

3. D. Matt, E. Veromann and A. Luik, Agronomy Research, 7(II), 662(2009).

4. O. A. Ogunwole, A. Y. P. Ojelade, M.O. Oyewo and E.A. Essien, International Journal of Food Science and Nutrition Engineering, 5(1), 59(2015).

5. Piešová, Z. Faixová, Z. Maková, K. Venglovská, L. Grešáková, S. Faix and K. Čobanová, Czech Journal of Animal Science, 64(3), 99(2019), DOI:10.17221/148/2018-cjas

6. A. R. Hayden, Journal of Food Science, 46(6), 1810(1981), DOI:10.1111/j.13652621.1981.tb04492.x

7. P. M. Silitonga, M. Silitonga and M. Nugrahalia, Jurnal Biosains, 4(2), 92(2018), DOI:10.24114/jbio.v4i2.10417

8. E. E. Onbaşlar, F. T and Aksoy, Livestock Production Science, 95(3), 255(2005), DOI:10.1016/j.livprodsci.2005.01.006

9. T. Seven, Asian-Australasian Journal of Animal Sciences, 21(8), 1164(2008), DOI:10.5713/ajas.2008.70605

10. W. K. Kim and P. H. Patterson, Journal of Environmental Science and Health, Part B, 40(4), 675(2005), DOI:10.1081/pfc-200061598

11. J. M. Matxain, M. Ristilä, Å. Strid and L. A. Eriksson, Chemistry-A European Journal, 13(16), 4636(2007), DOI:10.1002/chem.200700002 
12. O. Kucuk, A. Kahraman, I. Kurt, N. Yildiz and A. C Onmaz, Biological Trace Element Research, 126(1-3), 165(2008), DOI:10.1007/s12011-008-8190-Z

13. H. Chen, K. Mai, W. Zhang, Z. Liufu, W. Xu and B. Tan, Fish \& Shellfish Immunology, 19(3), 241(2005), DOI:10.1016/j.fsi.2004.12.006

14. G. E. Bugos, Business History Review, 66(1), 127(1992), DOI:10.2307/3117055

15. P. M. Silitonga and M. Silitonga, in Prosiding SEMIRATA bidang MIPA BKS-PTN Barat, Lampung, Indonesia, pp. 171-179 (2015).

16. S. Lieberman and N. Bruning, The real vitamin and mineral book: A definitive guide to designing your personal supplement program. Penguin, New York, NY, USA (2007).

17. M. Asaduzzaman, M. S. Jahan, M. R. Mondol, M. A. Islam and A. K. Sarkar, International Journal of Poultry Science, 4(8), 589(2005), DOI:10.3923/ijps.2005.589.595

18. L. Zemková, J. Simeonovová, M. Lichovníková, and K. Somerlíková, Czech Journal of Animal Science, 52(4), 110(2008), DOI:10.17221/2269-cjas

19. M. Kumar and A.E. Axelrod, The Journal of Nutrition, 96(1), 53(1968), DOI:10.1093/jn/96.1.53

20. M. Fathi, I. Al-Homidan, G. Rayan, S. El-Safty, T. Ebeid and O. Abou-Emera, Czech Journal of Animal Science, 64(5), 216(2019), DOI:10.17221/221/2018-cjas

21. F. A. Al-Obaidi, S. J. M. Al-Shadeed and R. H. Al-Dalawi, International Journal of Poultry Science, 10(5), 381(2011), DOI:10.3923/ijps.2011.381.385

22. L. Lv, L. Li, R. Zhang, Z. Deng, T. Jin and G. Du, Pakistan Journal of Zoology, 51(1), 49(2018), DOI:10.17582/journal.pjz/2019.51.1.49.55

23. S. Silaban, S. Gaffar, M. Simorangkir, I. P. Maksum and T. Subroto, IOP Conference Series: Earth and Environmental Science, 217012039 (2018), DOI:10.1088/1755-1315/217/1/012039

24. M. Simorangkir, B. Nainggolan and S. Silaban, Journal of Physics: Conference Series, 1374 012016(2019), DOI:10.1088/1742-6596/1374/1/012016

25. S. Silaban, S. Gaffar, M. Simorangkir, I. P. Maksum and T. Subroto, Journal of Physics: Conference Series, 1374 012047(2019), DOI:10.1088/1742-6596/1374/1/012047

26. M. Simorangkir, W. Hutabarat, B. Nainggolan and S. Silaban, Rasayan Journal of Chemistry, 12(2), 959(2019), DOI:10.31788/rjc.2019.1225095

27. A. A. Parikesit and U. S. F. Tambunan, Rasayan Journal of Chemistry, 11(3), 1133(2018), DOI:10.31788/RJC.2018.1133038

28. K. V. Balakrishnan, B. A. Mahdii, S. A. Mahdi, B. M. Abdullah, N. Hairunisa, H. Z. Huri, A. E. Ibrahim and E. A. Yousif, Rasayan Journal of Chemistry, 10(1), 176(2017), DOI:10.7324/RJC.2017.1011568

29. E. Conn and P. Stumpf, Outlines of Biochemistry, John Wiley \& Sons (2009).

[RJC-5506/2019] 